\title{
Dialogue with families: an opportunity to build the Decalogue of school sport in a participatory way
}

\begin{abstract}
This paper presents the phases that families at three teaching centres went through to draw up their own behaviour decalogues in school sport competitions and deploy courses of action to improve the behaviour of families when they act as spectators. The teaching centres are located in the Basque Country, Bizkaia province (Spain). The schools have spent four years working on a range of research projects in a bid to transform school sport in such a way as to bring it into line with the educational philosophy of each school, since in the vast majority of cases school sport entails excessive levels of violence and unethical behaviour. Each step of the process was made possible by the actions of the sport coordinators who were responsible for providing the link between the seminary and the families through the help of the centre group.
\end{abstract}

Keywords: decalogue, school sport, families, behaviours, competitions
Volume 2 Issue 4 - 2017

\author{
Vizcarra Maria Teresa, Rekalde Itziar, \\ Macazaga Ana María \\ University of the Basque Country, Spain
}

Correspondence: Vizcarra Maria Teresa, University of the Basque Country, Spain, Email: mariate.bizkarra@gmail.com

Received: December 02, 2017 | Published: December 27, 2017

\section{Introduction}

\section{From our conception of school sport to participational construction of the decalogue}

The concept of school sport on which we are basing our experience is set in the Historical Territory of Bizkaia (Basque Country, Spain) and this is regulated by Bizkaia's Diputación Foral (Provincial Council), governed by the regional regulations of the Basque Government. This government takes the view that School Sport covers sport activities at teaching centres outside actual school teaching hours and outside sport federations, that it is of an imminently formative and educational nature and that the main objective is sport as a way of life and not as a high-performance competitive activity.

The teaching centres studied in this paper strive to ensure that sport activities are governed by the same ethical codes as the other educational and academic activities carried on at the school. ${ }^{1}$ In previous research we succeeded in approaching a concept of School Sport reconstructed by the various agents at the three schools, in view of the importance attached by the three to School Sport and in connecting the philosophy of School Sport to the school's own educational philosophy (Educational School Project) and our investigations commenced at this point. In the research group, after conducting a review of our own conceptions and consulting all the educational agents at the schools (pupils, families, teachers, sport coaches and head teachers), we created a common language in relation to what we understand by School Sport, since here we are referring to a physical fun activity with a socializing component, in which those in charge of education have a defined pedagogical intention on the issue. With respect to the fun component, we feel this differs from other definitions, since in our conception the fun component need not signify a quality physical activity, because the quality of School Sport will depend on the values that are attributed to it and on the educational nature of any proposals submitted. On certain occasions the game is characterized by unfair competition, long periods of inactivity for most of the children, dominance of play by only a few and in general an implicit acceptance of inappropriate sporting values. ${ }^{2-4}$ Thus we feel that sports and games have great pedagogical potential, which must be discovered by educators if it is to be realized..$^{5-7}$

The sport is a game with rules and that these constitute the standard for behaviour patterns or beliefs, since the rules explain who takes control in critical situations and what kind of sanction or solution is applied to undesirable forms of behaviour. ${ }^{8}$ In School Sport, the rules ought to be adapted to the characteristics of each participant. ${ }^{9}$ Schools are institutions with an enormous social responsibility and that the school must be at the service of society: schools understood as institutions are intended to attempt to serve the community and society in a broader sense. We must examine how knowledge is created and legitimized through them..$^{10}$ They should not be closed off to potential contributions by pupils, since we feel that rules which merely impose sanctions do not educate and thus we are in favour of the participation of each pupil involved in sport and their families in drawing up the rules. ${ }^{11-12}$ The rules governing co-existence should be agreed upon, established and where necessary applied through participational procedures in which the pupils ought to play a major role; we should approach them, ask them how they see us, how they perceive us. Our point of view is that there should be a process of reflection as to who is responsible for making taking decisions with regard to rules, because we feel that not all rules are the sole responsibility of the educator and the issue of organization is at the very heart of the responsibilities of a teacher. It is, however, important to note that decisions relating to organization of the class are not the exclusive remit of the teacher; they ought to be taken in accordance with the pupils. ${ }^{13}$ The possible involvement of pupils in setting the rules leads us to a situation ${ }^{14}$ in which the teacher induces observance of rules that have been agreed upon by consensus consensuated and accepted by the group itself, because they are the reflection of the priority values and social-moral development we wish to foster among the members of that group.

The School Sport we believe in has a competitive component that may tend to seek out sporting excellence, or to achieve a collective benefit for one's own group with attitudes of respect, hard work, the spirit of accomplishment surpassing with the intention of doing the right thing and playing fairly. ${ }^{15}$ These competitive activities should 
serve to encourage positive values, ${ }^{2,12}$ and that competitions and their context should be conceived to give all the participants a reasonable chance of succeeding, in such a way as to enable them to overcome personal barriers. In the search for performance: There is a tendency to enhance the feelings of competence and incompetence with respect to physical activities. The game does not contain any teachings, nor is there any real commitment to creating a situation in which all pupils can develop appropriate sporting behaviour patterns and skills and also learn to feel good about themselves and their bodies. ${ }^{13}$

The belief that sport enhances work on values is one aspect to which the seminar attaches great importance, but all this could be foiled by competition focused in the wrong direction. Our idea of competition is a confrontation in which it is necessary to show respect to all participants, be tolerant with different attitudes and establish links of friendship through proximity and attempt to get to know the other person, thereby allowing empathy to be developed between sportsmen and sportswomen. ${ }^{7}$ This means that competition will teach girls and boys to be patient and to boost an image of themselves as patient or self-disciplined persons, by encouraging delays in gratification, understanding the values that influence personal development. Moreover, sport in education should create an atmosphere that does not ridicule children who have difficulties learning certain skills; ${ }^{13,16}$ an atmosphere in which attention is not paid solely to the most capable; an atmosphere that does not require competitive situations with technical resolution before this has been fully mastered; a situation that evaluates both effort and achievement, where the model of the champion athlete is not the sole criterion for a successful learning process.

We have already mentioned the socialization capacity of sport and in the same vein Trepat writes of the privileged space this affords us to work on positive values, though there is always the risk that we may be implementing intentions other than those we originally intended to implement. It is generally accepted that concepts such as camaraderie, the fighting spirit, knowing how to win, knowing how to lose graciously, respect for the rules are developed through playing sport. However, on the subject of values, it is understood that sport and competition can develop both positive and negative values, depending on the educational focus we are attempting to implement. The positive social values are cooperation, concern for others and respect for the various capabilities of others. On the other hand, the negative social values are being an egoist, being an individualist instead of working with others, valuing victory at any price, disdaining those who are different or who have difficulties with their movements. ${ }^{3}$

In our work on values we cannot forget the families. There is an obvious need to carry out this work in coordination with the families, who must boost, motivate and stimulate their children at all times, without straying from the values that educational sport must promote, irrespective of the results obtained in the sport concerned. That certain social agents such the family, the media and the school with its teachers and monitors exert a great influence on educating children about values. So it was that, on the basis of a number of working initiatives and campaigns with families, ${ }^{12,17}$ we began this process of education and awareness among families through a number of research projects. The Basque Government's sport violence committee has found that one of the main causes of violence in sport is rooted in school sport. More specifically, it claims that violence does not stem from the pupils, but rather from their families, whose behaviour influences the education of pupils, who are eventually caught up in the spiral of violence. This led to the preparation of a survey on to how to take preventive action that would palliate these violent attitudes in families. Our research is based on these hypotheses and we perceive the potential opportunity, relevance and interest of our work in connection with any educational community.

\section{What were the reasons behind this project?}

We had conducted our investigations over four dimensions:

i. The need to coordinate School Sport and compulsory Physical Education classes

ii. The values implemented by School Sport

iii. Satisfaction with School Sport at the respective teaching centres

iv. The characteristics of School Sport towards which all efforts should be directed

The survey noted the need to prevent undesirable types of behaviour in families and the following research project worked towards this goal, which consisted of investigating which attitudes were considered undesirable by families, using an observation sheet to record the attitudes and this eventually produced a questionnaire, which we used to allow families to self-assess their behaviour patterns. The research revealed the necessity to create our common decalogue that would help us involve ourselves in the change of attitudes and this is the research covered by the paper.

\section{Research methodology in the decalogue creation process}

We availed ourselves of a research-action seminar to try to grasp the needs of the educational community, in a bid to draw up a transforming survey which would educate the participants as they carried out their research, ${ }^{18,19}$ and would induce them to revise their own attitudes to their children's competition at school. Those involved were asked to contribute as active participants in the research. This was done so that requests for change would come from those who best understood what actually needed to be changed.

The families of the schools involved were treated as a case study, since this provides us with an in-depth survey of an event ${ }^{19}$ (Figure 1). There are three realities for the three schools and these converge at the seminar meetings (the global case). At the ikastolas, the coordinators created the "Centre Groups" containing a representative of all the groups and this helped us carry through all the discussion groups. ${ }^{18,19}$ Our desire to comprehend the day-to-day educational realities of the attitudes adopted by the families to School Sport competition at each ikastola induced us to opt for an ethnographic study, to be carried out in situ. All the information from the educational process was drawn up from field notes taken at the seminar sessions. The approximate duration of the seminars was three hours and they were recorded in audio format. After listening to and transcribing the recordings, these were reviewed and the field notes were drawn up to set out all the comments and incidents during the sessions, whereupon the three university researchers categorized the notes and put them in order to the common criterion of inductive hermeneutic analysis.

The purpose of the study was to review and reflect on the attitudes provoked in the families by competition in School Sport, with the purpose of drawing up a decalogue that would set out desirable attitudes on the part of this group of families (Figure 2). The participants were the families, the coordinators, the seminar and the centre groups at 
three Basque-language schools in Bizkaia province (Seber Altube in Gernika, Betiko in Leioa and Azkue in Lekeitio).

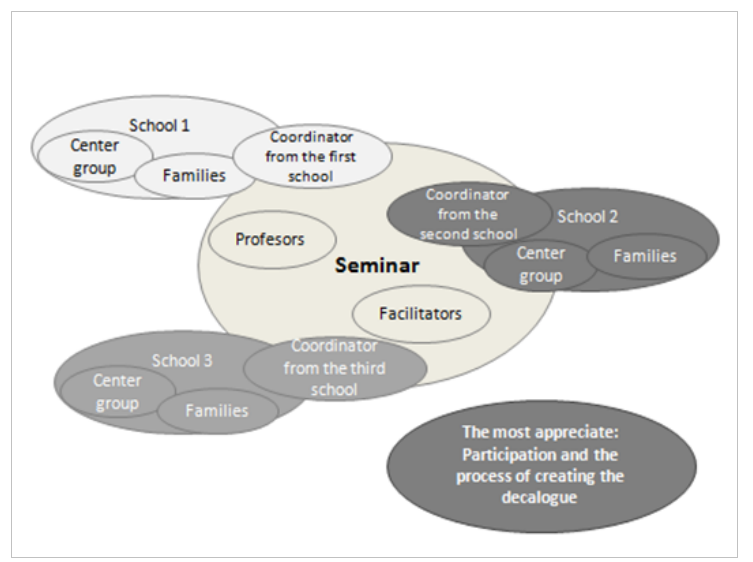

Figure I The visual representation of the global case.

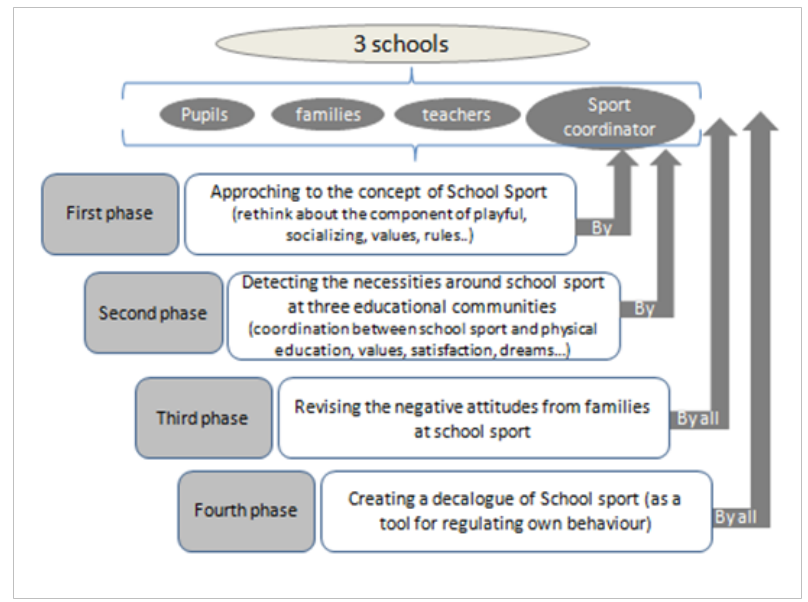

Figure 2 The sequence of the phases according to the purpose.

\section{The objectives were:}

i. To draw up the declaration of principles at each centre for School Sport based on the Centre Education Project, a specific feature of each educational reality.

ii. To review the attitudes and behaviour patterns of the families and develop a training process that would give rise to the creation of a decalogue in which the families would feel they were playing a key role.

iii. To create awareness of the effects of certain attitudes on schoolgirls and schoolboys.

\section{The structures involved in the research project and their functions}

i. The Seminar carries out research and training activities and is composed of a BIE representative, three researchers representing the ikastolas taking part in the project (School Sport coordinators) and three University researchers.

ii. The Centre Group carries out research and training activities. There is a centre group for each ikastola and this is a working group composed of the following: the researcher representing the ikastola taking part in the seminar, the Physical Education teacher, a teacher at the school, a School Sport monitor, a representative of the families and a representative of pupils in the secondary school. It presents the study to the families at the meetings, to which family groups are invited and streamlines the discussion groups at the educational sessions in order to generate the decalogue and reflect on attitudes. Assisted by the coordinator, it conducts interviews and questionnaires, collates field notes, analyses them and contrasts the partial reports with the families.

iii. The Family Groups are the groups targeted by the project as the mothers and fathers of pupils involved in School Sport and they participate on a voluntary basis.

Following we can see at Figure 3 some of the joint task that the different structures did to obtain the purpose along those months.

\begin{tabular}{|c|c|c|}
\hline Who? & What? & When? \\
\hline $\begin{array}{l}\text { - Center groups } \\
\text { - Families } \\
\text { - School sport } \\
\text { coordinators }\end{array}$ & $\begin{array}{l}\text { 1st. task. Meeting with the families, and applying a } \\
\text { brainstorm technique, they can express their interests } \\
\text { on desired behaviors. } \\
\text { 2nd. task. Preparing a draft of the decalogue with the } \\
\text { center group, summarizing the ideas presented at the } \\
\text { meeting. } \\
\text { 3rd. task. Presenting the draft of the decalogue to } \\
\text { families in order to make contributions. }\end{array}$ & January \\
\hline $\begin{array}{l}\text { - Seminar } \\
\text { - University teachers } \\
\text { (facilitators) } \\
\text { - School sport } \\
\text { coordinators } \\
\text { - Center groups }\end{array}$ & $\begin{array}{l}\text { 4th. task. Each center send its decalogue to the } \\
\text { facilitators, who elaborate a single document that } \\
\text { gathers the common aspects of the three centers. } \\
\text { 5th. task. Agreeing and contrasting the joint } \\
\text { decalogue or decalogue of the global case. } \\
\text { 6th. task. Disseminating the decalogues and } \\
\text { experience in the centers through panels. }\end{array}$ & Febreary \\
\hline \begin{tabular}{|l|} 
- Families \\
- Center groups
\end{tabular} & $\begin{array}{l}\text { 6th, task: Community reflection with families. Each } \\
\text { center group collects the information provided by the } \\
\text { families through the field notes. }\end{array}$ & May \\
\hline
\end{tabular}

Figure 3 The sequence of the phases according to the purpose.

\section{How did the process evolve? The participants carry out a dialogue}

To draw up the decalogue, training sessions were held with the families where the consequences of the behaviour patterns they adopt in the education of their children were questioned. The issues discussed up to that point were classified in the following dimensions attitudes on interpersonal relationships, attitudes in relation to the result of the game, attitudes in relation to the decisions taken by referees and coaches and attitudes on fair play. The field notes set out the ideas that would assist the Centre Group in drawing up the decalogue. Construction of the decalogue commenced with a brainstorming process during the corresponding training session, after which the Centre Group drew up a decalogue as a proposal by each school on the basis of the minutes of the meeting and the opinions gathered during the sessions. The three decalogues were compared and proposed for discussion by the facilitators and this produced the common decalogue for the three centres. This was to be publicly displayed at each school, with boxes for suggestions. Time was taken to reflect on the attitudes and to make comments concerning what was found to be desirable by each group. 
At the end of the discussion, we used the last 20minutes to draw some conclusions. I threw out one and they then began to join in. Seeing that people were beginning to respond, I asked questions such as: Do you see these meetings as a positive thing? What are your views on creating a decalogue? And I noted down their comments as they made them. In the Centre Group later, using these conclusions and the field notes, we classified the ideas in the four dimensions and created the decalogue from the dimensions (coordinator 2).

The members of the Centre Group decided the procedure for contrasting the notes gathered. The person taking notes was to contrast his or her notes with the other members of the Centre Group in attendance at the end of the sessions. When I arrived we had a quick look over the documentation, we added a few things and I told them that were enough and that we would analyze it in more depth at the Centre Group meeting (Coordinator 2). All the material was sent to the facilitators in such a way that we could see how closely the process for construction of the decalogues was being followed.

The material to be sent is the field notes with the reflections of the families, already contrasted by the Centre Group if possible, the recordings of the training session and the decalogue drawn up by the Centre Group (Coordinator 1). In our work as facilitators, we set out in a single document the aspects in which the three schools agreed and aspects that were mentioned by only one of them. The aim was to give back an overview to each centre of how the decalogue was being carried out at all the centres, to enable people in each Centre Group to perceive the trajectory covered. The joint decalogue was produced at the February seminar, drawn up by the facilitators from the decalogues produced by each centre. The coordinators showed it to the families at the centres and it was the subject of discussion at the seminar in March, in the knowledge that it was still subject to modification.

I focused on two or three of the things that were said that what is important to get involved, go to the matches and concern ourselves with the pupils. What is important is to get involved and, when we have the decalogue, to make sure it reaches all the families. Hold a meeting at the beginning of the school year to present the decalogue and explain the methodology that will be followed by the coaches (coordinator 1).

\section{An Appraisal was carried out in may of the process, the product and the experiment overall}

\section{Appraisal of the experiment}

The item most appreciated in this research project was not that there was a decalogue on the behaviour patterns that families should adopt with regard to competition, but the actual process of creating the decalogue and the reflections generated during this process. These reflections gave them the chance to gain a new understanding of School Sport in their role as spectators and made them realise how important their attitudes are. About 5 or 6 years ago a School Sport decalogue was created at the ikastola. I really don't know which is better or worse, but the difference between both of them lies in participation and that's what I see as most important. I think the involvement of all the people at the ikastola gives it a boost that the previous decalogue did not have, pretty as it might have been. Also, I think we were all quite satisfied with the result and so that just adds to the general level of satisfaction (Coordinator 3).
The coordinators gave us some very positive feedback on the appraisals of the families, though they feel that all the effort put into it should be used to advantage by working with the material and so they are laying the foundations for the next research project: besides completing the decalogue, some very good conclusions were drawn; though it might seem easy, the consensus reached is significant. Logically, all the agents at the ikastola took part and that was noticeable in the result. The families are proud of their work and so is the Centre Group.

Selling the product will be extremely important and we have to tie up any loose ends for next year so we can really work on it. It's a tool we should be using and so working in the Centre Group is very positive because ideas and ways of working arise spontaneously (even though it is not the time to talk about these now), they have discussed the possibility of working through tutorials, sport weeks etc. Apart from all that, what we have here is a tool that can easily produce some wonderful output (Parents 1). The coordinators see the decalogue as a tool which helped them in their reflections on School Sport philosophy at the centre, clearing up any misunderstandings and allowing a greater number of people to act with an attitude in closer proximity to what the coordinators wanted: It was useful to me for debating and working with the agents involved in School Sport. Normally it's easier for us to work alone or internally when we're thinking up a philosophy and targets for sport at the school. It's obvious with this experiment that the more consensus there is, the more people will identify with it and will take an active part in relation to sport at our school (Coordinator 1).

The Centre Group succeeded in implementing a forum for sharing ideas and experiences, creating an atmosphere of reflection which questioned every issue from the point of view of the other party: The Centre Group served as a space for people from different backgrounds with different points of view to share a common objective. It was an enriching exercise and that makes the result all the more valid. We were made to think, we had to draw conclusions and after all that attitudes and behaviour patterns have certainly changed (those most closely involved in School Sport say they have changed in practice, too). This conclusion was shared by everyone (Parents, 3 ).

One of the aspects most appreciated by the families in the decalogue construction process was that it gave them the chance to reflect with family members and coaches on the way sport is treated: it enabled me to reflect on my behaviour and my attitude as a mother at games, training sessions, etc. I have realized that our attitude is a decisive factor in the future behaviour patterns of our sons and daughters and how easy it is to get it wrong. It has made me reflect and think that some things can change and that families must be educated on this issue (parents 1). They feel that there is still much to be done, that the process is slow and the effort considerable, but we knew that before we started. They are now suggesting that work should continue with the decalogue and that an educational school sport project (PDEC) be initiated.

\section{Conclusion}

The review of the needs expressed by the various groups revealed the importance of having a set of consensuated ideas on the behaviour of families.

i. An attempt was made to involve all the project players through the Centre Groups. This contact allowed them to reflect on a joint 
basis and gave them the chance to listen to arguments from the point of view of the other person.

ii. A decalogue was created for each centre to reflect its educational philosophy and this has helped specify which kinds of behaviour are desirable.

iii. Participation of the families and the other project players was encouraged, the attitudes and behaviour patterns with respect to School Sport competition were reviewed and an awareness campaign was implemented on the impact of certain attitudes on pupils.

iv. Research-training teams were created at the teaching centres through those taking part in the seminars and collective reflection dynamics were built with regard to Physical Education and School Sport at ikastolas in Bizkaia forming part of the Bizkaia Ikastola Federation.

v. The decalogue construction process put them in a position where they had to think about issues to which they had previously paid no attention and this was an excellent starting point to implement a process of change.

We would not wish to conclude this text without expressing our gratitude to the coordinators, who made it possible to start up and streamline this experiment in their schools. ${ }^{20}$

\section{Acknowledgements}

None.

\section{Conflict of interest}

The author declares no conflict of interest.

\section{References}

1. Rekalde I, Vizcarra MT, Macazaga AM. La observación como estratégia de investigación para construir contextos de aprendizaje y fomentar procesos participativos. Educación XX1. 2014;17(1):201-220.

2. Rossi T, Tinning R, Cuaig L. With the best of intentions: a critical discourse analysis of physical education curriculum materials. Journal of teaching in physical education. 2009;28(1):75-89.

3. Tinning R. Baggy T-shirts, reeboks, schooling, popular culture and young bodies. Agora for Educación Física. 2011;1:49-54.

4. Vizcarra MT, Macazaga AM, Rekalde I. El proceso de acompañamiento en la construcción participativa de una normativa. Revista Española de Orientación y Psicopedagogía. 2013;24(1):110-120.
5. Bailey R, Armour K, Kirk D, et al. The educational benefits claimed for physical education and school sport: an academic review. Research Papers in Education. 2009;24(1):1-27.

6. Bolter N, Weiss M. Coaching for Character: development of the sportsmanship coaching behaviors scale (SCBS) port. Exercise and Performance Psychology. 2012;1(2):73-90.

7. Macazaga AM, Rekalde I, Vizcarra MT. Cómo encauzar la agresividad? Una propuesta de intervención a través de juegos y deporte. Revista Española de Pedagogía. 2013;255(71):263-276.

8. Weinberg R, Gould D. Fundamentos de psicología del deporte y el ejercicio físico. Spain: Ariel Psicología; 2010.

9. Casamayor G. Cómo dar respuesta a los conflictos. Spain: Graó; 2000.

10. Kirk D. The idea of the idea of physical education: Between essentialism and relativism in studying the social construction of physical education. Journal de la Recherche sur l'Intervention en Éducation Physique et Sport. 2009;18:24-40.

11. Figueras S, Calvo J, Capllonch M. Prevención y resolución del conflicto en educación física desde la perspectiva de los adultos miembros de la comunidad educativa en las comunidades de aprendizaje. Retos Nuevas tendencias en Educación Física, Deporte y Recreación. 2014;25(1):168173.

12. Fitzgerald H, Kirk D. Identity work: young disabled people, family and sport. Leisure Studies. 2009;28(4):469-488.

13. Tinning R. Educación Física: la escuela y sus profesores. Spain: University of Valencia; 1992.

14. Hellison D. Teaching responsibility through physical activity. USA: Human Kinetics; 2011. 224 p.

15. Price MS, Weiss MR. Peer leadership in sport: relationships among personal characteristics, leader behaviors and team outcomes. Journal of Applied Sport Psychology. 2011;23(1):49-64.

16. Vizcarra MT, Macazaga AM, Rekalde I. How conflicts are resolved in three learning communities? Journal of Psychodidactics. 2016;21(2):281-301.

17. Sánchez J, Molinero O, Yagüe JM. Incidencia de dos metodologías de entrenamiento-aprendizaje sobre la técnica individual de futbolistas de 6 a 10 años de edad. Retos Nuevas tendencias en Educación Física, Deporte y Recreación. 2012;22:29-32.

18. Habermas J. Theory of communicative action. Spain: 1994.

19. Flick U. The design of qualitative research. Spain: 2004.

20. Barbour R. Los Grupos de discusión en la Investigación Cualitativa. Spain: 2013. 